\title{
Strategi Manajemen Krisis Public Relations TNI Angkatan Laut dalam Menghadapi Pandemi Covid-19
}

\author{
https://doi.org/10.25008/wartaiski.v3i02.72
}

\author{
Infra Wahdaniah ${ }^{1}$, Umaimah Wahid ${ }^{2}$ \\ ${ }^{1,2}$ Magister Ilmu Komunikasi, Universitas Budi Luhur \\ Jl. Raya Ciledug-Kebayoran Lama, Jakarta Selatan 12260 - Indonesia \\ *e-mail korespondensi: infrawahdaniah@gmail.com
}

Submitted: 22/11/2020, Revised: 13/12/2020, Accepted: 21/12/2020

Accredited by Kemristekdikti No. 30/E/KPT/2019

\begin{abstract}
All over the world, without exception, are currently facing the pandemic crisis of the corona virus deseases 19 (Covid-19), including the Indonesian Navy. This research is to find out how the Public Relations crisis management strategy the Indonesian Navy in the face of the Covid-19 pandemic. Especially with the appointment of the Navy Hospital Dr. Mintohardjo as the Covid-19 referral hospital. The roles and functions of Public Relations in the Indonesian Navy are carried out by the Indonesia Navy Information Service. Dispenal is tasked with buliding, maintaining and enhancing the image of the Indonesian Navy. During the Covid-19 Pandemic, Dispenal must have a crisis management strategy. The crisis management strategy used as a reference in this study is based on the concept expressed by Wunderman Thompson by considering the stages of the crisis, namely Readiness, Radar, Response, and Recovery. This research uses a qualitative approach with constructive positivists. Data collection was carried out through observation, interviews, and documentation. The results showed that the Indonesian Navy used Wunderman Thompson's crisis management strategy, starting from the readiness stage by forming a Covid-19 Task Force Team, radar making SOP and crisis management responses by monitoring and evaluation, response using 3 scenarios, and recovery using make anaalysis towars a new normal life.
\end{abstract}

Keywords: Covid-19; pandemic; crisis management; public relations, Indonesia Navy information service;

\begin{abstract}
Abstrak
Di seluruh dunia tanpa kecuali kini sedang menghadapi krisis pandemi corona virus deseases 19 (Covid-19), tidak terkecuali TNI Angkatan Laut. Penelitian ini untuk mengetahui bagaimana strategi manajemen krisis Public Relations Tentara Nasional Indonesia Angkatan Laut (TNI AL) dalam menghadapi pandemi Covid-19. Terlebih dengan ditetapkannya Rumah Sakit Angkatan Laut Dr. Mintohardjo sebagai rumah sakit rujukan Covid-19. Peran dan fungsi Public Relations TNI AL dilaksanakan oleh Dinas Penerangan TNI AL (Dispenal). untuk membangun, mempertahankan, dan meningkatkan citra TNI Angkatan Laut. Di masa pandemi Covid-19, Dispenal memiliki strategi manajemen krisis. Strategi manajemen krisis dalam penelitian ini didasarkan pada konsep Wunderman Thompson dengan mempertimbangkan tahapan krisis yang terjadi: readiness, radar, response, dan recovery. Penelitian ini menggunakan pendekatan kualitatif dengan positivis konstruktif. Pengumpulan data dilakukan melalui observasi, wawancara, dan dokumentasi. Hasil penelitian menunjukkan, TNI AL menggunakan strategi manajemen krisis Wunderman Thompson, mulai dari tahapan readiness, membentuk Tim Satuan Tugas (Satgas) Covid-19; radar, membuat response manajemen SOP dan krisis dengan melakukan monitoring dan evaluasi; response, menggunakan tiga skenario; dan recovery, dengan membuat analisa menuju kehidupan normal baru.
\end{abstract}

Kata kunci: Pandemic; covid-19; manajemen krisis; public relations; dinas penerangan TNI AL. 


\section{PENDAHULUAN}

Pandemi Corona Virus Deseases-19 (Covid-19) sejak awal tahun 2020 telah membuat perubahan di muka bumi tanpa terkecuali. Dunia mengalami krisis di berbagai bidang yang bermula dari bencana kesehatan ini. Berbagai upaya dilakukan untuk menghadang penyebaran virus berbahaya tersebut, termasuk pemerintah Indonesia yang harus bekerja keras untuk mengatasi pandemi tersebut. Dunia dihadapkan pada pilihan sulit: mengutamakan kesehatan atau ekonomi. Mendahulukan kesehatan menyebabkan ekonomi perlahan-lahan lumpuh. Begitu pula sebaliknya, mendahulukan aspek ekonomi dengan mengabaikan aspek kesehatan dapat mengakibatkan bencana kesehatan.

Hingga pertengahan November 2020 sudah 220 negara terpapar Covid-19. Total kasus Covid19 di seluruh dunia mencapai 55,6 juta jiwa. Dari jumlah itu, penderita Covid-19 yang sembuh mencapai 35,8 juta jiwa dan meninggal dunia sebanyak 1,34 juta jiwa. Sedangkan di Indonesia, total kasus mencapai 488 ribu jiwa pasien dengan rincian, sembuh 411 ribu, dan meninggal 15.678 ribu jiwa (BNPB, 2020).

Kondisi Covid-19 yang belum tahu kapan berakhirnya ini makin merontokkan perekonomian banyak negara. Pertumbuhan ekonomi semakin melambat, tidak hanya di Indonesia, tetapi juga di negara lain yang selama ini ekonominya jauh di atas Indonesia, seperti Amerika Serikat, Jepang, Korea Selatan, Uni Eropa, Hongkong, dan Singapura. Berdasarkan data Badan Pusat Statistik (BPS), pertumbuhan ekonomi Indonesia pada kuartal II 2020, berada di level -5,32\%. Keadaan ini mencemaskan karena penurunannya begitu cepat. Angka tersebut berbanding terbalik dengan kuartal II tahun 2019, yaitu 5,05\% (BI, 2020).

Prasyarat berjalannya ekonomi harus dilandasi dengan kesehatan masyarakat dan sumber daya manusia lainnya. Tidak ada satu pilihan di antara keduanya, semua harus berjalan bersama. Jadi apapun pilihannya antara, ekonomi dan Kesehatan: apakah ekonomi dulu atau kesehatan lebih dahulu bukan pilihan mudah karena semua beresiko. Sehingga yang diperlukan adalah perhatian dan kehatihatian melalui pilihan-pilihan terbaik untuk kepentingan dan kesejahteraan rakyat.

Pemerintah Indonesia saat ini mengerahkan segala upaya untuk mengatasi pandemi, termasuk pelibatan Tentara Nasional Indonesia (TNI) yang mempunyai tugas pokok menjaga kedaulatan wilayah Negara Kesatuan Republik Indonesia sesuai ketentuan Pasal 7 Ayat (1) Undang-Undang No. 34 Tahun 2004 tentang TNI. Keterlibatan TNI dalam operasi militer bukan perang juga merupakan amanah UU No. 34 Tahun 2004 yang memberi ruang TNI melakukan tugas militer selain perang.

TNI AL sebagai bagian dari institusi TNI sejak awal turut andil langsung dalam menghadapi bencana Covid-19. Sebagai institusi negara yang mengelola rumah sakit di berbagai wilayah tanah air, rumah sakit TNI AL (RSAL) dilibatkan sebagai rumah sakit rujukan dalam menangani Covid 19. Meskipun begitu, sebagai rumah sakit kedinasan, terdapat acuan kebijakan khusus agar segala sesuatunya dapat berjalan tanpa masalah.

Dalam rangka kedinasan, terdapat tugas-tugas rutin yang dilakukan untuk memberikan jaminan kesehatan kepada prajurit TNI AL dan keluarganya. Pada bagian lain RSAL sebagai institusi negara wajib membantu pemerintah dan masyarakat menghadapi Covid-19. Berdasarkan Keputusan Menteri Kesehatan Republik Indonesia Rumah Sakit TNI AL Mintohardjo merupakan rumah sakit rujukan penanggulangan penyakit infeksi emerging tertentu. RSAL Dr. Mintohardjo memiliki 197 tempat tidur yang siap digunakan membantu penanganan Covid-19. Sebanyak 112 prajurit TNI AL di rumah sakit Dr. Mintohardjo, mulai dari pangkat kelasi hingga kolonel, selalu siap membantu pasien Covid-19. (Satgas Covid-19, 2020).

Di Jakarta, selain RSAL Mintohardjo, terdapat Rumah Sakit Marinir Cilandak (RSMC) yang tidak ditunjuk sebagai rumah sakit rujukan. Meskipun sama-sama sebagai institusi milik negara di bawah pengelolaan TNI AL, Rumah Sakit Marinir Cilandak tidak ditunjuk sebagai rumah sakit rujukan emerging tertentu. Situasi seperti ini perlu diperjelas melalui sosialisasi dan cara-cara lain yang informatif agar tidak memicu reaksi negatif dari masyarakat dalam hal pelayanan rumah sakit, khususnya RSAL.

Kurun waktu pandemi yang tidak pasti kapan akan berakhir, berpotensi memicu anggapan masyarakat yang membutuhkan layanan kesehatan, seperti penolakan pasien oleh rumah sakit, karena tidak semua pihak bisa langsung menerima atau memahami sehingga perlu penjelasan yang baik dan menyeluruh. Sosialisasi yang tidak maksimal dapat mengundang permahaman yang salah sehingga bisa memicu persoalan di masyarakat dan berdampak negatif bagi institusi. 
Pada 11 Maret 2020, Organisasi Kesehatan Dunia (World Health Organization/WHO) menetapkan corona virus disease 2019 (Covid-19) sebagai pandemi global. Seluruh warga dunia berpotensi terkena infeksi penyakit itu. WHO menyatakan Covid-19 merupakan darurat internasional. Artinya, setiap rumah sakit diminta mempersiapkan diri dan menangani pasien penyakit tersebut. Setiap negara didorong untuk mendeteksi, mengetes, merawat, mengisolasi, melacak, dan menggerakkan masyarakatnya untuk memerangi pandemi tersebut.

Di Indonesia, Pandemi Covid-19 mendapatkan penanganan yang serius dengan dikeluarkannya Keputusan Menteri Kesehatan Republik Indonesia Nomor HK.01.07/Menkes/169/2020 tanggal 10 Maret 2020 tentang Penetapan Rumah Sakit Rujukan Penanggulangan Penyakit Infeksi Emerging Tertentu. Salah satu dari 129 rumah sakit rujukan penanggulangan penyakit infeksi emerging tertentu itu adalah RSAL Mintohardjo.

RSAL Mintohardjo memiliki tugas: melakukan penatalaksanaan dugaan kasus yang berpotensi kejadian luar biasa Penyakit Infeksi Emerging Tertentu; memberikan pelayanan rujukan pasien dan rujukan spesimen yang berkualitas sesuai dengan standar; meningkatkan kapasitas sumber daya yang diperlukan dalam rangka penatalaksanaan dugaan kasus yang berpotensi kejadian luar biasa Penyakit Infeksi Emerging Tertentu; dan melakukan pencatatan dan pelaporan. Sebagai rumah sakit rujukan, RSAL mendapatkan penggantian biaya perawatan pasien penyakit infeksi emerging sesuai dengan ketentuan peraturan perundang-undangan.

Di era teknologi informasi yang serba cepat membutuhkan data yang cepat dan akurat. Bila informasi tidak akurat menyebar dengan cepat, tentu akan menimbulkan pemahaman dan merugikan, khususnya bagi TNI AL. Atas dasar uraian di atas, penelitian ini berupaya mengetahui strategi manajemen krisis public relations Tentara Nasional Indonesia Angkatan Laut dalam menghadapi masa pandemi Covid-19.

\section{KERANGKA TEORI}

Wilcox dan Cameron dalam buku Dasar-Dasar Public Relations, menyatakan public relations merupakan sebuah fungsi manajemen atas sebuah sikap yang direncanakan dan dilaksanakan secara berkelanjutan oleh setiap organisasi demi mendapatkan saling pengertian, dukungan, dan simpati dari masyarakat, terkait dengan cara melakukan evaluasi opini masyarakat tentang organisasi untuk mencapai kerja sama yang produktif dan efisien (Wilcox dan Cameron, 2006).

Scott M. Cutlip, Allen H. Center dan Glen M. Broom (2006) mendefinisikan fungsi manajemen dari public relations, yaitu membangun dan mempertahankan hubungan baik dan bermanfaat antara organisasi atau perusahaan dengan publik yang mempengaruhi sukses atau gagalnya organisasi. Ruslan (1999) mengungkapkan, terdapat empat peran utama public relations, yaitu sebagai komunikator atau penghubung antara organisasi atau perusahaan dengan publiknya; membina hubungan dengan berupaya membina hubungan positif dan saling menguntungkan dengan publiknya; peran back up management, sebagai pendukung dalam fungsi manajemen organisasi atau perusahaan; membentuk corporate image, yang berperan menciptakan citra positif bagi organisasi atau perusahaan.

Peran dan fungsi puclic relations dapat terwujud dengan adanya strategi yang terencana sesuai dengan tujuan yang ingin dicapai dalam perusahaan atau organisasi. Menurut Ahmad S. Adnanputra, strategi public relations adalah alternatif optimal yang ditentukan agar dapat mencapai tujuan dalam rencana public relations yang tertuang dalam kerangka terencana. Strategi dipilih untuk mencapai hasil, seperti pernyataan dalam sasaran yang sudah dipastikan (Ruslan, 1999)

Public Relations diartikan oleh Frank Jefkins dalam Daniel Yadin sebagai bentuk komunikasi yang terencana ke dalam maupun ke luar antara suatu organisasi dengan semua khalayaknya dalam rangka mencapai tujuan spesifik, berlandaskan saling pengertian. Keberadaan public relations dalam sebuah organisasi sangat ditentukan oleh bagaimana manajemen organisasi itu dalam memahami urgenitas membangun hubungan strategis dengan publiknya. Meski demikian, fungsi public relations tergantung pada sistem organisasi dalam perusahaan maupun lembaga (Yadin, Daniel, 2004).

Harison dalam Kriyantono (2006) menjelaskan, krisis merupakan suatu keadaan kritis yang berkaitan dengan berbagai kemungkinan yang berpengaruh negatif terhadap organisasi, sehingga diperlukan keputusan cepat dan tepat agar tidak mempengaruhi keseluruhan organ organisasi. Menurut Machfud (1998), krisis adalah suatu kejadian, dugaan atau keadaan yang mengancam keutuhan, reputasi, atau keberlangsungan individu atau organisasi. Hal tersebut mengancam rasa aman, kelayakan 
dan nilai-nilai sosial publik, bersifat merusak baik secara aktual maupun potensial pada organisasi, dimana organisasi itu sendiri tidak dapat segera menyelesaikannya.

Menurut Robert P. Powell (2005), krisis adalah kejadian yang tidak diharapkan, berdampak dramatis, kadang belum pernah terjadi sebelumnya yang mendorong organisasi kepada suatu kekacauan (chaos) dan dapat menghancurkan organisasi tersebut.

Krisis tidak memiliki batas dan dapat terjadi kapan saja, dimana saja, terhadap setiap organisasi, baik profit dan nonprofit, publik dan privat. Krisis dapat terjadi tanpa pandang bulu, artinya dapat melanda berbagai organisasi atau perusahaan, baik besar maupun kecil, dan tanpa memperhatikan situasi geografi atau reputasi.

Manajemen krisis dapat diartikan sebagai suatu bentuk respon dan upaya dalam menyikapi serta memecahkan masalah dari krisis melalui strategi manajemen krisis yang mungkin untuk dilakukan. Penyelesaian krisis harus ditanggapi dengan serius oleh manajemen perusahaan atau organisasi dengan merancang crisis management plans untuk mencegah meluasnya krisis dengan menerapkan strategi manajemen krisis yang tepat untuk meminimalisir resiko kesalahan (Murray, 2001).

COE Wunderman Thompson, Marianne Admardatine menyatakan, penting bagi institusi/korporasi/lembaga memiliki sistem manajemen krisis yang terdiri dari panduan komunikasi krisis dan mitigasi krisis (PR Indonesia, 2019).

Terdapat sistem 4R (readiness, radar, response, recovery) sebagai panduan komunikasi krisis yang disusun dengan runut. Readiness, membentuk tim khusus manajemen krisis yang terdiri dari penasihat krisis dan pakar media sosial. Radar, membuat response managemen SOP and crisis, dengan melakukan monitoring dan evaluasi pesan untuk menentukan skala prioritas. Response, membuat skenario respons untuk masing-masing tingkat urgensi pesan, dengan kode pesan: hijau, kuning, dan merah. Recovery, membuat analisa pembangunan reputasi dengan melakukan audit strategi dan taktik media sosial.

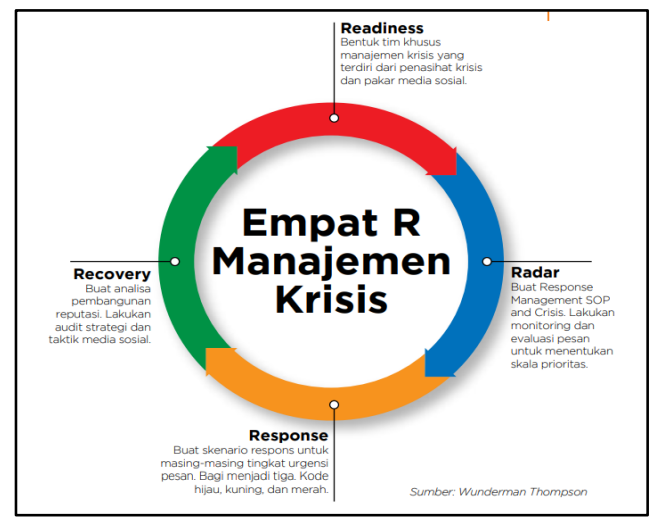

Diagram1. Empat R Manajemen Krisis

\section{METODE PENELITIAN}

Penelitian ini menggunakan pendekatan kualitatif dengan cara deskriptif. Tujuannya untuk menggambarkan situasi yang terjadi secara sistematis dan mendalam berdasarkan fakta yang terjadi. Jenis penelitiannya adalah studi kasus karena terdapat kekhususan di dalam institusi militer. Teknik pengumpulan data dilakukan melalui observasi, wawancara, dan dokumentasi.

Data yang diperoleh dari rumah sakit dilaporkan kepada pimpinan melalui Tim Satuan Tugas (Satgas) Covid-19 yang sudah ditetapkan melalui surat telegram Kasal nomor 015/SREN/0320 tanggal 18 Maret 2020. Tim Satgas melibatkan Dinas Kesehatan Angkatan Laut (Diskesal), Dinas Penerangan Angkatan Laut (Dispenal), Dinas Informasi dan Pengolahan Data Angkatan Laut (Disinfolahtal), dan Pusat Komando dan Pengendalian Angkatan Laut (Puskodal).

Peneliti mewawancarai Wakil Ketua Satgas Covid-19 bidang Penerangan dan Wakil Ketua Satgas Covid-19 bidang Teknologi Informasi, mewakili Tim Satgas Covid-19 TNI AL sebagai informan. Semua data yang ada dilaporkan kepada pimpinan melalui Tim Teknologi Informasi, selanjutnya informasi yang sudah dikelola dengan baik disampaikan oleh Satgas bidang penerangan.

Untuk menguji keabsahan data dilakukan triangulasi (Moleong, 2010). Peneliti memeriksa dari berbagai perspektif disesuaikan dengan hasil wawancara. Kemudian data yang diperoleh di lapangan 
dianalisis melalui tahapan manajemen krisis yang dikemukakan CEO Wunderman Thompson Marianne Admardatine, untuk selanjutnya ditarik kesimpulan.

\section{HASIL PENELITIAN}

Pada tahun 1945 TNI Angkatan Laut berdiri dengan nama Badan Keamanan Rakyat (BKR) Laut, kemudian menjadi Tentara Keamanan Rakyat (TKR) Laut, dan Angkatan Laut Republik Indonesia (ALRI). Sejak berdiri TNI Angkatan Laut, fungsi penerangan sudah ada dengan nama Bagian Penerangan. Ketika organisasi angkatan laut dipimpin oleh Menteri/Panglima Angkatan Laut pada tahun 1963, bagian penerangan berubah menjadi Pusat Penerangan Angkatan Laut. Tahun 1984 hingga sekarang namanya menjadi Dinas Penerangan TNI Angkatan Laut (Sejarah TNI AL, 2012).

Dispenal melaksanakan peran dan fungsi public relations sesuai dengan Peraturan Presiden Nomor 66 Tahun 2019, yaitu menyelenggarakan pembinaan penerangan, meliputi penerangan pasukan; penerangan umum; produksi penerangan; multimedia dan konter opini dalam rangka mendukung tugas TNI Angkatan Laut. Dispenal sebagai public relations TNI Angkatan Laut dituntut untuk selalu hadir dan mampu berkomunikasi secara efektif dalam mengkomunikasikan berbagai hal terkait keangkatanlautan (Perpres 66, 2019).

Dalam penyampaian komunikasi pada organisasi TNI termasuk di dalamnya TNI Angkatan Laut terdapat kekhususan dibandingkan dengan organisasi lainnya, namun tetap berlangsung secara wajar. Pimpinan TNI mengeluarkan peraturan tentang kewenangan pemberian keterangan pers. Dalam peraturan tersebut dijelaskan siapa saja yang memiliki kewenangan dalam menyampaikan informasi terkait kebijakan pimpinan masing-masing matra.

Selain Pusat Penerangan (Puspen) TNI, Dinas Penerangan TNI Angkatan Darat (Dispenad), Dinas Penerangan TNI Angkatan Laut (Dispenal), Dinas Penerangan TNI Angkatan Udara (Dispenau), informasi terkait pandemi Covid juga dikeluarkan oleh Tim Satuan Tugas (Satgas) Pandemi Covid-19. Satgas ini dibentuk karena dibutuhkan dalam situasi emergensi dan krisis.

Pandemi Covid-19 merupakan situasi emergensi bukan hanya di TNI Angkatan Laut, tapi terjadi secara menyeluruh di berbagai negara. Satgas Covid-19 TNI AL perlu mencari solusi agar masyarakat terlebih prajurit dan pegawai negeri sipil (PNS) di lingkungan TNI AL menjadi tenang dan kondusif (tnial.mil.id, 2020).

Wakil Ketua Satgas Covid-19 bidang teknologi informasi mengungkapkan, TNI AL melakukan manajemen krisis berdasarkan konsep Wunderman Thompson. Terdapat 4R tahapan krisis, yaitu readiness, radar, response, dan recovey. TNI AL melakukan tahapan $\mathrm{R}$ pertama yaitu readiness dengan membentuk tim Satgas Covid-19 melibatkan Diskesal, Dispenal, Disinfolahtal, dan Puskodal (Satgas Covid-19 TNI AL).

Tim ini dibentuk supaya informasi terkelola dengan baik, dan dapat dikendalikan agar manajemen organisasi berjalan dengan lancar. Tim ini dibentuk dari segala sektor yang memungkinkan untuk berperan, termasuk diantaranya dalam kaitan dengan media sosial, komunikasi publik yang dilaksanakan oleh Dispenal. Disinfolahtal mengumpulkan data-data sehingga terkumpul secara terpadu, baik data pasien, data kesiapan seluruh rumah sakit, alat peralatan, personel, dukungan itu semua disiapkan. Data tersebut dipadukan sehingga informasinya lebih mudah disampaikan. Tim Satgas ditunjuk sebagai penanggung jawab monitoring dan memberikan saran serta pertimbangan kepada pimpinan berdasarkan surat telegram Kasal nomor 015/SREN/0320 tanggal 18 Maret 2020.

Setelah itu lanjut ke R kedua, radar. Pada tahapan ini TNI AL membuat respons manajemen SOP dan krisis, yang diawali dengan melakukan monitoring dan evaluasi pesan untuk menentukan skala prioritas. Data pasien dari seluruh rumah sakit, baik nasional maupun internal TNI AL, data kesiapan alat peralatan, dukungan personel, dikumpulkan dan dipadukan sehingga menjadi informasi yang siap untuk disampaikan ke Satgas Covid-19 Nasional. Dokter TNI AL juga diikutkan dalam Satgas Covid19 nasional agar langkah Satgas Covid-19 TNI AL sama dengan Satgas Covid-19 Nasional.

Langkah selanjutnya adalah tahapan $\mathrm{R}$ yang ketiga, yaitu response. Pada tahapan ini dibuat skenario untuk masing-masing urgensinya. Skenario pertama adalah skenario tertinggi, disebut sebagai Siaga Satu. Setiap skenario terbagi dua, skenario intern dan ekstern. Untuk intern (ke dalam) pada skenario pertama adalah dukungan terhadap penanganan Covid di intern seperti personel, rumah sakit, obat-obatan, peralatan dengan mekanisme penanganan sosial distancing, serta penanganan jenazah dan penanganan pasien akut bagi prajurit maupun pegawai negeri sipil (PNS) TNI AL. Penanganan ekstern (keluar), TNI AL menyiapkan personel, tenaga kesehatan, rumah sakit, penanganan jenazah, 
penanganan pasien akut dan kesiapan penanganan sosial umum lainnya untuk penanggulangan di tingkat nasional.

Skenario kedua adalah skenario menengah yang disebut dengan Siaga Dua. Pada skenario ini tidak seluruh sumber daya dikerahkan. Mekanisme kerja masih wajar, dilakukan dengan separuh kekuatan. Kemudian skenario ketiga yaitu new normal (normal baru), semua bekerja seperti biasa dengan menerapkan protokol kesehatan yang lebih tinggi dari sebelumnya. Pada skenario ketiga ini seluruh sumber daya pengerahannya menggunakan model wajar.

Tahap $\mathrm{R}$ terakhir adalah recovery, yaitu pemulihan dengan membuat analisa pembangunan reputasi. Dengan skenario yang dilakukan pada tahap response maka diperoleh kemajuan-kemajuan yang berhasil dihimpun, sehingga skenario 1 yang dilakukan pada bulan Juni berubah menjadi skenario kedua. Skenario kedua berubah menjadi skenario ketiga. Skenario ketifa merupakan kehidupan new normal (normal baru). Sekarang recovery menuju normal baru, semua sudah menuju skenario ketiga, yaitu normal baru dengan tetap menerapkan protokol kesehatan.

Setelah melalui tahapan 4R, maka proses tersebut diinformasikan secara umum kepada masyarakat menggunakan strategi komunikasi secara aktif dengan positivis konstruktif. Informasi yang disampaikan secara positif untuk mengkonstruksi diri dan keyakinan TNI AL serta masyarakat umum bahwa pandemi bisa diatasi, sehingga diperoleh sikap yang positif dari masyarakat, tetap optimis untuk segera mengatasi persoalan, karena ketika orang pesimis dan tidak yakin bahwa pandemi bisa diatasi, maka orang tersebut bisa rapuh untuk terpapar Covid-19. Sebaliknya apabila sikap seseorang positif dapat mengatasi persoalan pandemi, maka akan lebih mudah mengatasi permasalahan yang ada.

Seperti dikutip dari www.aladokter, pola pikir dapat mempengaruhi tingkat kesehatan seseorang. Orang yang berpikir positif cenderung lebih sehat, karena mampu menghadapi stres yang dimilikinya dengan baik. Mereka cenderung lebih mudah menjalani gaya hidup sehat, sehingga tidak rentan terserang penyakit. Berpikir positif juga mampu menjaga keseimbangan kinerja organ tubuh dan hormon di dalamnya, sehingga dapat menjaga daya tahan tubuh tetap optimal.

Implementasi strategi yang dilakukan melalui strategi internal dan eksternal. Strategi internal dengan tetap menekankan sikap positif, keyakinan (saat new normal), mengelola mulai dari rumah sakit, personel, pembiayaan dan mekanisme kerja sesuai dengan protokol kesehatan melaui komunikasi berjenjang (sesuai dengan fungsi komando) dan kontinyu disertai pengendalian dan pengawasan pelaksanaannya. Selain melakukan komunikasi verbal melalui konferensi pers (ke luar), dan apel (ke dalam), dilakukan juga komunikasi melalui media internal maupun aturan-aturan pendukung seperti peraturan Panglima TNI, surat edaran, dan lain sebagainya.

Wakil Ketua Satgas Covid-19 bidang penerangan mengungkapkan, kebijakan-kebijakan pimpinan TNI AL disampaikan kepada seluruh prajurit dan PNS TNI AL (internal) dan masyarakat (eksternal) melalui majalah Cakrawala, lembar penerangan pasukan (Penpas), twitter, WhatsApp, instagram, website TNI AL (www.tnial.mil.id), radio Jalesveva Jayamahe (Radio JJM), televisi Jalesveva Jayamahe (TV JJM), Webinar TNI AL.

Penerangan secara verbal secara rutin dan berkala juga disampaikan kepada seluruh prajurit dan PNS TNI AL. Pimpinan TNI AL, Laksamana TNI Yudo Margono juga melakukan konferensi pers dengan menyampaikan mengenai penanganan Covid-19 yang dilakukan di internal TNI AL maupun kepada masyarakat umum.

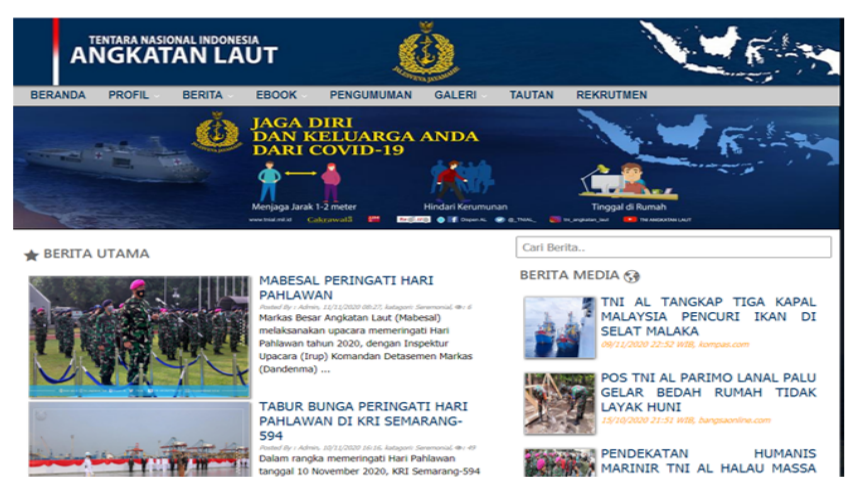

Gambar 1. Website TNI AL (tnial.mil.id)

Sumber: Dispenal 
Implementasi Strategi Eksternal yaitu melalui media cetak, elektronik, maupun online, yang menginformasikan berbagai dukungan yang dilakukan TNI AL dalam penanganan pandemi Covid-19 yang terdiri dari tenaga-tenaga kesehatan, rumah sakit-rumah sakit, personel untuk mengimplementasikan pembatasan sosial berskala besar (PSBB) maupun kebijakan new normal yang diterapkan dari pemerintah di lapangan, termasuk protokol kesehatan, dengan $3 \mathrm{M}$ (Menjaga jarak, Mencuci tangan, Memakai masker).

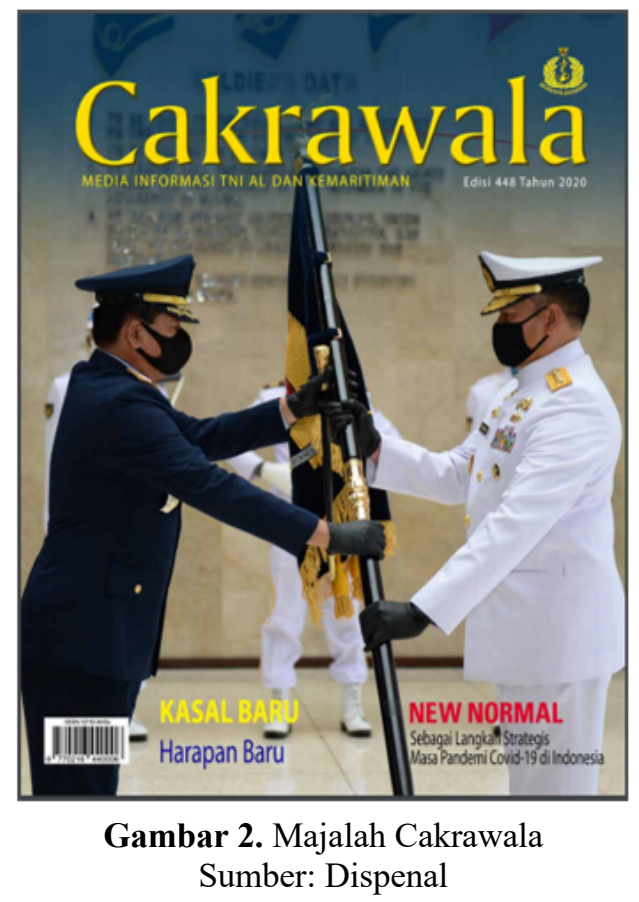

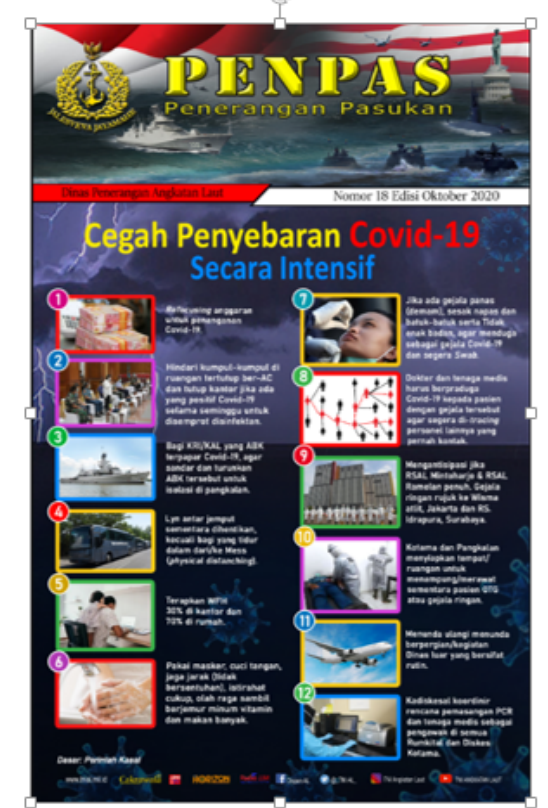

Gambar 3. Lembar Penerangan Pasukan Sumber: Dispenal

\section{KESIMPULAN}

TNI Angkatan Laut dalam menghadapi masa pandemi Covid-19 menggunakan konsep strategi manajemen krisis dari Wunderman Thompson melalui tahapan 4R yaitu readiness, dengan membentuk Tim Satgas Covid-19, radar, response, dengan melalui tiga skenario dan recovery sebagai tahap pemulihan. Proses tersebut diinformasikan secara aktif kepada masyarakat dengan menggunakan strategi komunikasi positivis konstruktif.

Komunikasi dilakukan dengan mengimplementasikan melalui lembar penerangan pasukan (Penpas), majalah Cakrawala, twitter, instagram, WhatsApp, website TNI AL (www.tnial.mil.id), radio Jalesveva Jayamahe (Radio JJM), televisi Jalesveva Jayamahe (TV JJM), webinar TNI AL, dan penerangan verbal secara rutin dan berkala kepada seluruh prajurit maupun PNS TNI TNI AL.

Informasi yang disampaikan secara positif untuk mengkonstruksi kepercayaan diri dan keyakinan TNI AL serta masyarakat umum bahwa pandemi bisa diatasi, sehingga diperoleh sikap yang positif dari masyarakat, tetap optimis untuk segera mengatasi persoalan

\section{DAFTAR PUSTAKA}

Butterick, K. (2012). Pengantar Public Relations: Teori dan Praktik. Jakarta: Rajagrafindo Persada. Badan Pusat Statistik. (2020). Ekonomi Indonesia Triwulan II 2020 Turun 5,32 Persen, diundur dari https://www.bps.go.id/pressrelease/2020/08/05/1737/-ekonomi-indonesia-triwulan-ii-2020turun-5-32-persen.html

Denzim, N.K., Lincoln, Y.S. (2009). Handbook of Qualitative Research. Yogyakarta. Pustaka Pelajar. Kasali, R. (2018). Manajemen Public Relations Konsep dan Aplikasinya di Indonesia. Jakarta: Pustaka Utama Grafiti.

Keputusan Menteri Kesehatan Republik Indonesia Nomor HK.01.07/Menkes/169/2020 tanggal 10 Maret 2020, tentang rumah sakit rujukan penanggulangan penyakit infeksi emerging tertentu

Kriyantono, R. (2012). Public Relations \& Crisis Management Pendekatan Critical Public Relations Etnografi Kritis \& Kualitatif. Jakarta: Kencana. 
Moleong, L. J. (2010). Metodologi Penelitian Kualitatif. Bandung: Remaja Rosdakarya.

Murray. (2001). Public Relations. Berkshire: Hodder \& Stoughton Ltd.

Nova, F. (2009). Crisis Public Relations: Bagaimana PR Menangani Krisis Perusahaan. Jakarta: Grafindo.

Patton, M. Q. (2009). Metode Evaluasi Kualitatif. Yogyakarta: Pustaka Pelajar.

Peraturan Pemerintah Republik Indonesia Nomor 66 Tahun 2019 Tanggal 18 Oktober 2019 tentang Susunan Organisasi Tentara Nasional Indonesia.

PR Indonesia. Edisi 56 Th V. (2019). Pentingnya Memiliki Panduan Krisis. Jakarta: Aksara Grafika Pratama.

Regester, M., Judy, L. (2008). Risk Issues and Crisis Management, Fourth Edition. London: Kogan Page.

Ruslan, R. (1999). Manajemen Humas dan Manajemen Komunikasi. Jakarta: Raja Grafindo Persada.

Sejarah TNI Angkatan Laut. (2012). Dinas Penerangan TNI Angkatan Laut.

Sugiono. (2009). Metode Penelitian Kuantitatif Kualitatif dan R\&D. Bandung: Alfabeta.

Suparno, L. (2011). Crisis Management \& Public Relations. Jakarta: indeks.

Undang-Undang Nomor 34 Tahun 2004 Tanggal 16 Oktober 2004 tentang Tentara Nasional Indonesia

Wilcox, Cameron. (2006). Dasar-Dasar Public Relations, Jakarta: PT. Remaja Rosda Karya.

Yadin, D. (2004). Public Relations Frank Jefkins. Jakarta: Erlangga. 